\title{
Teaching Styles of Iranian EFL Teachers: Do Gender, Age, and Experience Make a Difference?
}

\author{
Mehrak Rahimi (Corresponding author) \\ English Department, Faculty of Humanities \\ Shahid Rajaee Teacher Training University, Lavizan, Tehran 1678815811, Iran \\ Tel: 98-21-2297-0035Ｅ-mail: mehrakrahimi@yahoo.com \\ Fatemeh Asadollahi \\ English Department, Faculty of Humanities \\ Shahid Rajaee Teacher Training University, Lavizan, Tehran 1678815811, Iran \\ Tel: 98-21-2297-0035Ｅ-mail: fatemehasadollahi@yahoo.com
}

$\begin{array}{lr}\text { Received: December 25, } 2011 & \text { Accepted: March 7, } 2012 \quad \text { Published: April 1, } 2012 \\ \text { doi:10.5539/ijel.v2n2p157 } & \text { URL: http://dx.doi.org/10.5539/ijel.v2n2p157 }\end{array}$

\begin{abstract}
The aim of this study was investigating Iranian EFL teachers' teaching styles and the activities they use most frequently in their classes. Additionally, the difference between male and female teachers' teaching styles and the relationship between teaching styles and teachers' experience and age were explored. Three hundred EFL teachers were selected by stratified random sampling from six districts of the capital city, Tehran. They filled in a personal information questionnaire and Teaching Activities Preference (TAP) questionnaire. The results of the study showed that the participants used a variety of teaching activities in English classes; however, they constituted a special group due to the high percentage of using sensing type activities. Further, it was found that male and female teachers were different in extroverting, sensing, and feeling styles of teaching while female teachers used activities related to these styles more than their male counterparts did. Besides, the obtained results revealed that EFL teachers' age and experience had a negative relationship with sensing style and a positive relationship with thinking style of teaching.
\end{abstract}

Keywords: Teaching styles, EFL, Teachers, Age, Experience

\section{Introduction}

Teaching style is one of the most important factors affecting the development of teachers' professional expertise (Akbari, Mirhassani, \& Bahri, 2005) that is always consistent with teachers' personality type and varies among individuals (Cooper, 2001). According to one definition from late seventies teaching style is "a pervasive way of approaching the learners that might be consistent with several methods of teacher" (Fischer \& Fischer, 1979, p. 246). This definition emphasizes the importance of teaching methods and the ability of the teacher to select the right approach for the class. Consequently, teaching styles tended to be equated with teaching approaches, as that was the mainstay of language teacher training at the time.

To Kaplan and Kies (1995), however, teaching style "consists of a teachers' personal behavior and the media used to transmit data to or receive it from the learner" (p. 2). This definition stresses the importance of teachers' behavior and media that significantly affect the delivery of the instruction. Terms such as 'initiating and responsive behavior' (Flanders, 1970) and 'progressivism and traditionalism' (Bennett et al., 1976) have also been used to refer to teaching styles. Therefore, teaching style refers to all of teaching techniques and activities and approaches that a teacher employs in teaching a certain subject in the classroom or "the sum total of instructional activities, techniques, and approaches that a teacher feels most comfortable using when he or she is in front of a class" (Cooper,2001, p. 301).

It is evident that teaching style is a very influential factor in students' learning experiences (Knowles, 1980) since teachers provide the "vital human connection between the content and the environment and the learners" 
(Heimlich \& Norland, 1994, p. 109) and because it stems from an educational philosophy that lends direction and purpose to a teacher's teaching (Galbraith, 1999). This claim about the effectiveness of teaching style is supported by a comprehensive body of research, especially in mainstream education, which links teaching style to student achievement outcomes (Conti, 1985; Miglietti \& Strange, 1998; Welborn, 1996). The existence of this rich body of research about teaching style is based on the premise that teachers do not all teach alike and that classroom teaching styles are not all equally effective (Baily, 1984).

However, most of the literature on teaching style does not refer to teaching a particular subject and therefore there is a dearth of information describing what teachers of particular subjects, e.g. EFL teachers, actually do in their classes. As teaching style "includes the implementation of philosophy; it contains evidence of beliefs about, values related to, and attitudes toward all the elements of the teaching-learning exchange" (Jarvis, 2004, p.40) more in- depth research across cultures and fields of study seems essential. Many studies have revealed that teachers' behavior and instructional performance vary due to the context of teaching such as private and public school or EFL and ESL setting (Korthagen, 2004), teachers' professional knowledge (Schelfhout et al., 2006), curriculum variables such as teaching materials (Cunningsworth, 1995), and learners and their learning styles (Oxford, 2002).

More recently there has been a surge of interest on scrutinizing the role of teachers' personal characteristics in their teaching preferences. Frequently the studies focus on how demographic variables such as gender, age, and experience influence teaching and learning styles (Severiens, 1997; Brew, 2002).

Gender is one crucial factor which might influence, in one way or another, teachers' professional lives in general and their teaching preferences in particular considering their personality and individual characteristics. It is believed that social relations and the dominance of either gender (usually male) affects teachers' lives (Karimvand, 2011). Female professionals are usually subordinate to male authorities in educational settings where professional interactions are usually characterized by marginalization of women (Bartlett, 2005). However, studies which have focused on how gender might affect teachers' choice of different teaching styles are a few and have shown different results (Karimvand, 2011). For instance, in a study of gender differences in Iran, Aliakbari and Soltani (2009) found that Kurdish females prefer active, reflective, sensing, intuitive, verbal and sequential styles except for the visual and global ones. They also found that Persian male EFL teachers and students prefer all styles including active, reflective, sensing, intuitive, visual, verbal, and global except for the sequential one.

Since teachers usually gain extensive experience of successful and unsuccessful performances throughout their years of teaching, this assumption has generated in-depth research into how teachers who have been involved in teaching for different periods of time perceive their teaching (Hoy \& Woolfolk, 1993; Imants \& Brabander, 1996 ; Fives \& Lisa, 2008; Fives, 2010; Soodak \& Podell, 1997; Campbell, 1996; Kotaman, 2010). Wolters and Daugherty (2007) found that teachers in their first year of teaching reported significantly lower self-efficacy for instructional practices and classroom management than did teachers with more experience. Soodak and Podell (1997) observed that experienced teachers are more resistant to change in their beliefs of personal efficacy and use of activities of different types than teachers with less experience. Also, there are some other studies which show mixed results, like Gorrell and Dharmadasa (1994), indicating that, although pre-service teachers preferred implementing new methods of instruction, experienced teachers were more concerned about classroom management and organization of instruction and their impacts on students. Finally, some researchers have reported no significant relationship between teachers' years of experience and their activity preference and/or efficacy beliefs (e.g., Guskey, 1987).

Although there is a body of research on the relationship between EFL experience and some teaching variables, there is a crucial need for more research on the relationship between teaching experience, age and teaching styles of EFL teachers in general and Iranian EFL teachers in particular. Hence, the present study aimed at finding answers to the following questions:

1). What are Iranian EFL teachers' teaching styles?

2). Is there a significant difference between male and female teachers' teaching styles?

3). Is there any relationship between Iranian EFL teachers' teaching experience and their teaching styles?

4). Is there any relationship between Iranian EFL teachers' age and their teaching styles? 


\section{Method}

\subsection{Participants}

Three hundred EFL teachers participated in this study. The sample were selected through stratified random sampling based on Krejcie and Morgan's (1970) formula with confidence level of 95\% (margin of error $=5 \%$ ) among 1000 English teachers who worked in 8 districts of the capital city, Tehran.

\subsection{Instruments}

Two data collection instruments were used in order to gather data for this study: a personal information questionnaire to make a profile of teachers' demographic variables and Teaching Activities Preference (TAP) questionnaire.

\subsubsection{Personal information questionnaire}

In order to make a profile of demographic variables including gender, age, teaching experience, type of English degree (TEFL, Translation, Linguistics, Literature, Others), level of education (AA, BA, and MA), class size, and type of school (private, public) a personal information questionnaire was used.

\subsubsection{Teaching Activities Preference (TAP) questionnaire}

This questionnaire was developed by Cooper (2001) to see how EFL teachers rate a variety of teaching activities in teaching English. He has designed the Teaching Activities Preference (TAP) questionnaire to include activities that have been shown to appeal to specific personality dimensions (Lawrence, 1997, pp. 47-80, and Myers \& Myers, 1998, p.265). It groups teaching activities in eight teaching styles: extroverts, introverts, sensing, intuitive, thinking, judging, perceiving, and feeling types. The questionnaire includes 20 items to be ratedon a 5 -point Likert scale, whereby "1" meant "I don't agree with the statement at all" and "5" meant "I fully agree with the statement".

Although this questionnaire has been used in a study in Iran (Akbari, Mirhassani, \& Bahri, 2005), there is no report of reliability estimation of the questionnaire. However, Cooper (2001) and Akbari, Mirhassani, and Bahri (2005) reported that TAP inventory turned out to be reliable in their studies. The adaption process for the questionnaire included translation and back-translation and reliability estimation. The reliability of the TAP questionnaire was estimated to be .81 in this study.

\section{Results}

\subsection{EFL teachers' teaching styles}

Descriptive statistics were used to portray Iranian EFL teachers' teaching styles (Table 1).As Table 1 shows, Iranian EFL teachers prefer sensing $(M=4.44)$, judging $(M=4.40)$, and thinking type activities $(M=4.29)$. They also make use of other activity categories including intuitive $(M=4.18)$, feeling $(M=4.15)$, extroverting $(M=$ 4.12), perceiving (3.95), and introverting type activities $(M=3.75)$.

\subsection{Male and female EFL teachers' teaching styles}

In order to find the differences between male and female Iranian EFL teachers with regard to their teaching styles, independent samples t-test were conducted. The result of the t-tests showed that male and female teachers were different in the following teaching styles: extroverting style, sensing style, and feeling type style (Table 2).

As the result of t-test shows ( $\mathrm{t}=3.88, p<.05)$, there is a significant difference between male and female EFL teachers in extrovert style of teaching. Examining the means shows that female teachers with a mean of 12.71 $(\mathrm{SD}=1.68)$ use extrovert type activities more than their male counterparts do (mean=11.85, $\mathrm{SD}=2.09)$. These activities include encouraging students to take part in discussions and information gap and group-based activities.

The result of t-test for sensing types shows that there is a significant difference between male and female EFL teachers in sensing style of teaching $(\mathrm{t}=4.15, p<.05)$. The mean comparison of two groups revealed that female teachers with a mean of 13.61 ( $\mathrm{SD}=1.38$ ) use sensing type activities more in comparison to male teachers (mean=12.87, $\mathrm{SD}=1.69$ ). These activities include hear-see-touch activities, pre-teaching activities, and activities that are done with audiovisual aids.

Further, the result of t-test for feeling types shows a significant difference between male and female EFL teachers in this style of teaching $(\mathrm{t}=2.81, p<.05)$. Examining the means shows that female teachers with a mean of $12.69(\mathrm{SD}=1.86)$ use feeling type activities more in comparison to male teachers (mean=12.06, $\mathrm{SD}=1.94$ ). Activities in this part include establishing personal rapport with students and incorporating small-group work in teaching activities whenever possible. 


\subsection{Teaching styles, experience, and age}

Correlation coefficient analysis was conducted to find the relationship between teaching styles, experience, and age. The result of correlation is illustrated in Table 3. As Table 3 shows, there is a negative and significant correlation between EFL teachers' age and experience with sensing style of teaching $(\mathrm{r}=-.12$ and $\mathrm{r}=-.13$ respectively) and a positive and significant correlation between EFL teachers' age and experience level with thinking style of teaching $(\mathrm{r}=.13$ and $\mathrm{r}=.15$ respectively).

\section{Discussion}

The aim of this study was investigating Iranian EFL teachers' teaching styles and the activities they use most frequently in their classes. Additionally, the difference between male and female teachers' teaching styles and the relationship between teaching styles and teachers' experience and age were explored.

The result of the study showed that Iranian EFL teachers employ all eight types of teaching styles in their language classes. The use of different teaching activities by Iranian EFL teachers is a promising finding that supports teachers' role in creating an effective learning environment (Sarvan \& Cakiroglu, 2003) even in an EFL program that suffers a lot of serious problems including teaching materials and methodology (Rahimi \& Nabilou, 2009). This can be related to the fact that isolating students' learning styles and motivation from teaching style is difficult and in some cases impossible (Kirkpatrick, 2011). Students prefer some styles of learning over others and each student learns in a special way. Some prefer to see, hear and touch, others like to think and make logical analysis at the same time, and some like to discuss the issues and interact with others. Therefore, it could be claimed that Iranian EFL teacher may employ a variety of styles and activities in order to involve students and satisfy individual learning needs.

Although the participants asserted that they use a variety of teaching styles, they constitute a special group due to the high percentage of using sensing type activities. They rely primarily upon the mental process (also called mental functions) of sensing, which attends to observable facts or happenings through one or more of the five senses. They stress the importance of using and teaching materials that are applicable for students outside the classroom walls, materials that deal with life issues, the orientation for providing concrete experiences first in any learning sequence and always including a practical reason for an assignment. One reason for this finding might be the fact that textbooks developed for EFL courses in Iran are old and do not follow the state-of-the-art scientific frameworks of applied linguistics in general and materials development in particular (Rahimi \& Nabilou, 2009) and they are not written according to Iranian students' needs and interest (Rahimi \& Hassani, 2011). As facilitating interest in subject matter is one of the most effective strategy for teaching English before the textbook is used (Cooper, 2001), Iranian EFL teachers employ sensing type activities including hear, touch, and see activities to motivate students and compensate for shortcomings of the textbook and other teaching/learning materials.

Further, it was found that female teachers prefer extroverting, sensing, and feeling style of teaching in comparison to male teachers, implying that Iranian female EFL teachers have extrovert, sensing, and feeling teaching styles. According to Myers et al. (1998) extraverts are oriented toward the outer world, "for they focus their energy on people and objects" (p. 6), sensing people rely primarily upon the mental process (also called mental functions) of sensing, which attends to observable facts or happenings through one or more of the five senses, and finally feeling people "rely primarily on the process of feeling to decide primarily on the basis of personal or social values" (p. 6). A detailed investigation of females' personality throughout the psychology reveals that they prefer to be with other people, take over events and ideas with others, take part in parties and group activities, and try to develop relationships with the people they meet (Hillguard, 1983). These in turn are the characteristics of extroverts according to Hillguard (1983). Females prefer organized materials, they are field-dependent, and they make use of their five senses in most of the occasions (characteristics of sensing people). Finally, as for the feeling people, females come to a decision more subjectively on the basis of their feelings and they are caring and kind-hearted. Therefore, it will be logical of the female teachers as being feeling, sensing, and extroverting people and prefer feeling, sensing, and extroverting types of activities.

Further, the correlational analysis revealed a negative relationship between sensing style of teaching and age and experience level of the EFL teachers. This negative relationship implies that experienced and older teachers have less interest to use sensing type activities in their classroom. Sensing-type teachers tend to emphasize facts and practical information. They like to provide students with concrete experiences in a learning sequence before using the textbook and think that students learn best from an orderly sequence of questions about a topic that results in predictable responses. The orientation for providing concrete experiences first in any learning sequence and always including a practical reason for an assignment is typical for sensing type teachers (Cooper, 2001). In 
the field of psychology sensing people are introduced as the individuals who prefer to take in sequenced information through the use of five senses, and are more interested in concrete and here-and-now actions which are, on the other hand, among the constituent elements of young peoples' personality. Therefore, as teachers become aged they lose their motives to use sensing activities and style of teaching.

In addition, for the novice teachers who enter the classroom with less even any experience of teaching it is important to appeal to their students and encourage them for learning (Zhenhui, 2001). Therefore, they would use sensing type activities to attract students. As time goes on, teachers find other ways of attracting learners and also their preferences change as they grow older, so they recede from these activities and styles.

The positive correlation of age and experience level with thinking style of teaching can be explained in the way that thinking type teachers are interested in cause-and-effect relationships and like to have logical reasons for doing things (Cooper, 2001). The positive correlation implies that older and experienced teachers have more interest to use these activities in the classroom. After years of service and gaining a repertoire of classroom skills and strategies, experienced teachers typically have the ability to prioritize tasks, organize thoughts, and select from among a number of key classroom matters and styles. They are logical and competent persons that can make right and proper decisions in different situations (Hagger \& McIntyre, 2000). A brief look at the psychology reveals that being objective, logical, impartial, and competent are among the characteristics of old and experienced people as they regardless of what people may think about them prefer to be just, determined, and competent. Therefore, it can be expected for the experienced and old teachers to prefer thinking type style of teaching and the corresponding activities in their classes.

\section{References}

Akbari, R., Mirhassani, A., \& Bahri, H. (2005). The relationship between teaching style and personality type of Iranian EFL teachers. Iranian Journal of Applied Linguistics (IJAL), 11, 1-28. Retrieved from hpp://www.sid.ir

Aliakbari, M., \& Soltani, N. (2009). Variation of learning styles among Iranian EFL learners: Effects of culture, language background and gender. Proceedings of the 16th Conference of Pan-Pacific Association of Applied Linguistics. Centre for Enhancing English Learning and Teaching: Hong Kong. Retrieved from www.paaljapan.org/conference2011/mate/CFP_16thPAAL.pdf

Baily, G. (1984). An Evaluator's guide to diagnosing and analyzing teaching style. NASSP Bulletin, 68, 19-25. http://dx.doi.org/10.1177/019263658406846903.

Bartlett, A. (2005). "She seems nice": Teaching evaluations and gender trouble. Feminist Teacher, 15, 195-202.

Bennett, N., Jordan. J., Long, G., \& Wade. B. (1976). Teaching styles and pupil progress. London: Open Books Publishing Limited.

Brew, R. (2002). Kolb's learning style instrument: Sensitive to gender. Educational and Psychological Measurement, 62, 373-90. http://dx.doi.org/10.1177/0013164402062002011.

Campbell, J. (1996). A comparison of teacher-efficacy for pre- and in-service teachers in Scotland and America. Journal of Education, 117, 2-12.

Conti, G., J. (1985). The relationship between teaching style and adult student learning. Adult Education Quarterly, 35, 220-228. http://dx.doi.org/10.1177/0001848185035004004

Cooper, C. (2001). Foreign language teaching style and personality. Foreign Language Annals, 34, 301-16. http://dx.doi.org/10.1111/j.1944-9720.2001.tb02062.x.

Cunningsworth, A. (1995). Choosing your coursebook. Oxford: Macmillan Heinemann.

Fischer, B., \& Fischer, L. (1979). Styles in teaching and learning. Educational Leadership, 36, 245-254. Retrieved from http://www.ascd.org/ASCD/pdf/journals/ed_lead/el_197901_fischer.pdf

Fives, H., \& Lisa, L. (2008). College instructors' sense of teaching and collective efficacy. International Journal ofTeaching and Learning in Higher Education, 20, 182-191. Retrieved from http://www.isetl.org/ijtlhe/pdf/IJTLHE330.pdf

Fives, H. (2010). Examining the factor structure of the teachers' sense of efficacy scale. Experimental Education, 78, 118-134. http://dx.doi.org/10.1080/00220970903224461

Flanders, A. (1970). Analyzing teacher behavior. MA: Addition-Wesley Publishing Company.

Galbraith, W. (1999). Philosophy and the instructional process. Adult Learning, 11, 11-13. 
Gorrell, J., \& Dharmadasa, H. (1994). Perceived self-efficacy of pre-service and in service Sri Lankan teachers. International Education, 24, 23-36.

Guskey, T., R. (1987). Context variables that affect measures of teacher-efficacy. The Journal of Educational Research, 81, 41-47

Hagger, H., \& McIntyre, D. (2000). What can research tell us about teacher education? Oxford Review of Education, 26, 483-495. http://dx.doi.org/10.1080/713688546

Heimlich, E., \& Norland, E. (1994). Developing teaching style in adult education. San Francisco: Jossey-Bass.

Hillguard, E. R. P. (1983). Psychological background. Translated by Rafiei, H. Tehran: Arjomand Publication.

Hoy, W. K., \& Woolfolk, A. E. (1993). Teachers' sense of efficacy and the organizational health of schools. The Elementary School Journal, 93, 356-372. Retrieved from http://www.jstor.org/stable/1002017

Imants, M., \& De Brabander, J. (1996). Teachers' and principals' sense of efficacy in elementary schools. Teaching and Teacher Education, 12, 179-195. http://dx.doi.org/10.1016/0742-051X (95)00053-M

Jarvis, P. (2004). Adult education and lifelong learning: Theory and practice. London: Routledge Falmer.

Kaplan, J., \& Kies, A. (1995). Teaching styles and learning styles: Which came first? Journal of Instructional Psychology, 22, 29-34.

Karimvand, P., N. (2011). The Nexus between Iranian EFL Teachers' self-efficacy, teaching experience and gender. English Language Teaching, 4, 171-183. http://dx.doi.org/10.5539/elt.v4n3p171

Kirkpatrick, R. (2011). Looking at a learning styles research paper: A critical evaluation. Asian EFL Journal, 52, 59-73. Retrieved from www.asian-efl-journal.com/PTA/May-2011-Kirkpatrick.pdf

Knowles, M., S. (1980). The modern practice of adult education: From pedagogy to andragogy. New York: Cambridge Books.

Korthagen, F. A. J. (2004). In search of the essence of a good teacher: Towards a more holistic approach in teacher education. Teaching and Teacher Education, 20, 77-97. http://dx.doi.org/10.1016/j.tate.2003.10.002

Kotaman, H. (2010). Turkish early childhood educators' sense of teacher efficacy. Electronic Journal of Research in Educational Psychology, 8, 603-616. Retrieved from http://investigacion-psicopedagogica.org/revista/new/english/ContadorArticulo.php?409

Krejcie, R., \& Morgan, D. (1970). Determining sample size for research activities. Educational and Psychological Measurement, 30, 607-610. http://dx.doi.org./10.1177/001316447003000308

Lawrence, G. (1997). Looking at type and learning styles. Gainesville, FL: Center for Applications of Psychological Type.

Miglietti, C., L., \& Strange, C., C. (1998). Learning styles, classroom environment preferences, teaching styles, and remedial course outcomes for underprepared adults at a two-year college. Community College Review, 26, 1-19. http://dx.doi.org/10.1177/009155219802600101

Myers, I., B., McCaulley, M., H, Quenk, N., L., \& Harmmer, A., L. (1998). MBTI manual: A guide to the development and use of the Myers-Briggs Type Indicator. Palo Alto, CA: Consulting Psychologists Press, Inc.

Myers, B., \& Myers, Q., K., D. (1998). Myers-Brigs type indicator; Form M. Palo Alto. CA: Consulting Psychologists Press, Inc.

Oxford, R. (2002). Language learning strategies. In R. Carter and D. Nunan. (Eds.). The Cambridge guide to teaching English to speakers of other languages (pp. 166-172). Cambridge: Cambridge University Press.

Rahimi, M., \& Nabilou, Z. (2009). Globalization and EFL curriculum reform in Iran: Challenges and opportunities. Journal of Technology of Education, 3, 115-124. Retrieved from http://www.sid.ir

Rahimi, M., \& Hassani, M. (2011). Attitude towards EFL textbooks as a predictor of attitude towards learning English as a foreign language. Procedia Social and Behavioral Sciences, 31, 66-72. http://dx.doi.org/10.1016/j.sbspro.2011.12.018

Sarvan, A., \& Cakiroglu, J. (2003). Preservice science teachers' orientations' to classroom management. Hacettepe Üniversitesi Egitim Fakültesi Dergisi, 26, 124-130. Retrieved from http://www.efdergi.hacettepe.edu.tr/english/abstracts/26/a16.htm

Schelfhout, W., Dochy, F., Janssens, S., Struyven, K., Gielen, S., \& Sierens, E. (2006). Educating for learning-focused teaching in teacher training: The need to link learning content with practice experiences within 
an inductive approach. Teaching and Teacher Education, 22, 874-897. http://dx.doi.org/10.1016/j.tate.2006.04.003

Severiens, S. (1997). Gender and learning. Learning styles, ways of knowing, and patterns of reasoning. Unpublished doctoral dissertation. University of van Amsterdam: Amsterdam.

Soodak, L., \& Podell, D. (1997). Efficacy and experience: Perceptions of efficacy among pre-service and practicing teachers. Journal of Research and Development in Education, 30, 214-219.

Welborn, R. (1996). Influences of achievement among non-traditional health professional students. Paper presented at the Teaching to Potential Regional Conference on University Teaching. ERIC Document Reproduction Service, ED 279258.

Wolters, C., A., \& Daugherty, S., G. (2007). Goal structures and teachers' sense of efficacy: Their relation and association to teacher experience and academic level. Journal of Educational Psychology, 99, $181-193$. http://dx.doi.org/10.1037/0022-0663.99.1.181

Zhenhui, R. (2001). Matching teaching styles with learning styles in East Asian contexts. The Internet TESL Journal. Retrieved from http://iteslj.org/Techniques/Zhenhui-TeachingStyles.html

Table 1. Descriptive Statistics for teaching styles

\begin{tabular}{|l|c|c|}
\hline Scale & Mean & SD \\
\hline Extroverting types & 4.12 & 1.893 \\
\hline Introverting types & 3.75 & 1.770 \\
\hline Sensing types & 4.44 & 1.549 \\
\hline Intuitive types & 4.18 & 1.739 \\
\hline Thinking types & 4.29 & 1.749 \\
\hline Feeling types & 4.15 & 1.911 \\
\hline Judging types & 4.40 & .754 \\
\hline Perceiving types & 3.95 & 1.018 \\
\hline
\end{tabular}


Table 2. The results of $\mathrm{t}$-tests

\begin{tabular}{|c|c|c|c|c|c|c|c|}
\hline Teaching styles & Group & Mean & SD & $\begin{array}{c}\text { Mean } \\
\text { difference }\end{array}$ & $t$ & $d f$ & Sig. \\
\hline \multirow[t]{2}{*}{ Extroverting } & Male & 11.853 & 2.090 & \multirow[t]{2}{*}{-.853} & \multirow[t]{2}{*}{-3.888} & \multirow[t]{2}{*}{298} & \multirow[t]{2}{*}{.000} \\
\hline & Female & 12.706 & 1.682 & & & & \\
\hline \multirow[t]{2}{*}{ Introverting } & Male & 11.163 & 1.850 & \multirow[t]{2}{*}{-.145} & \multirow[t]{2}{*}{-.695} & \multirow[t]{2}{*}{298} & \multirow[t]{2}{*}{.488} \\
\hline & Female & 11.309 & 1.719 & & & & \\
\hline \multirow[t]{2}{*}{ Sensing } & Male & 12.870 & 1.691 & \multirow[t]{2}{*}{-.743} & \multirow[t]{2}{*}{-4.155} & \multirow[t]{2}{*}{298} & \multirow[t]{2}{*}{.000} \\
\hline & Female & 13.614 & 1.382 & & & & \\
\hline \multirow{2}{*}{ Intuitive } & Male & 12.612 & 1.697 & \multirow[t]{2}{*}{.101} & \multirow[t]{2}{*}{.490} & \multirow[t]{2}{*}{298} & \multirow[t]{2}{*}{.624} \\
\hline & Female & 12.510 & 1.767 & & & & \\
\hline \multirow[t]{2}{*}{ Thinking } & Male & 12.913 & 1.796 & \multirow[t]{2}{*}{.065} & \multirow[t]{2}{*}{.318} & \multirow[t]{2}{*}{298} & \multirow[t]{2}{*}{.751} \\
\hline & Female & 12.847 & 1.723 & & & & \\
\hline \multirow[t]{2}{*}{ Feeling } & Male & 12.060 & 1.939 & \multirow[t]{2}{*}{-.629} & \multirow[t]{2}{*}{-2.812} & \multirow[t]{2}{*}{298} & \multirow[t]{2}{*}{.005} \\
\hline & Female & 12.690 & 1.857 & & & & \\
\hline \multirow[t]{2}{*}{ Judging } & Male & 4.387 & .8724 & \multirow[t]{2}{*}{-.019} & \multirow[t]{2}{*}{-1.481} & \multirow[t]{2}{*}{298} & \multirow[t]{2}{*}{.140} \\
\hline & Female & 4.407 & .6711 & & & & \\
\hline \multirow[t]{2}{*}{ Perceiving } & Male & 3.819 & 1.084 & \multirow[t]{2}{*}{-.213} & -1.775 & 298 & .077 \\
\hline & Female & 4.032 & .968 & & & & \\
\hline
\end{tabular}

Table 3. Correlation Matrix

\begin{tabular}{|c|c|c|c|c|c|c|c|c|c|c|}
\hline Variables & 1 & 2 & 3 & 4 & 5 & 6 & 7 & 8 & 9 & 10 \\
\hline 1 Age & 1 & $.87^{* *}$ & -.06 & .01 & $-.12^{*}$ & -.01 & $.13^{*}$ & -.01 & -.02 & -.02 \\
\hline 2 Experience & & 1 & -.01 & .02 & $-.13^{*}$ & .07 & $.15^{* *}$ & -.04 & -.03 & -.02 \\
\hline $3 \quad$ Extroverting & & & 1 & $.32^{* *}$ & $.46^{* *}$ & $.34^{* *}$ & $.23^{* *}$ & $.37^{* *}$ & .08 & .06 \\
\hline 4 Introverting & & & & 1 & $.19^{* *}$ & $.32^{* *}$ & $.33^{* *}$ & $.30^{* *}$ & .09 & .02 \\
\hline 5 Sensing & & & & & 1 & $.37^{* *}$ & $.25^{* *}$ & $.32^{* *}$ & .02 & .07 \\
\hline $6 \quad$ Intuitive & & & & & & 1 & $.37^{* *}$ & $.41^{* *}$ & .02 & .02 \\
\hline $7 \quad$ Thinking & & & & & & & 1 & $.30^{* *}$ & -.010 & -.05 \\
\hline $8 \quad$ Feeling & & & & & & & & 1 & .09 & .09 \\
\hline 9 Judging & & & & & & & & & 1 & $.30^{* *}$ \\
\hline 10 Perceiving & & & & & & & & & & 1 \\
\hline
\end{tabular}

** Correlation is significant at 0.01 level

* Correlations is significant at the 0.05 level 